\title{
PIM2 induced MMP-9 expression in macrophages requires PI3K and Notch1 signaling
}

\author{
Nisha Kapoor ${ }^{1}$, Kushagra Bansal', Germain Puzo ${ }^{2}$, Martine Gilleron², KN Balaji ${ }^{1 *}$ \\ From 7th European Workshop on Immune-Mediated Inflammatory Diseases \\ Noordwijk aan Zee, the Netherlands. 28-30 November 2012
}

\section{Introduction}

Granuloma formation during Mycobacterium tuberculosis infection represents pathological attributes of the host immunity to infection and is required for the containment of infection. Granuloma formation is a complex process involving initiation and development of organized multicellular structures comprised of components of extracellular matrix [1]. Activation of inflammatory immune responses during granuloma formation upon infection with mycobacteria is often associated with tissue remodeling and breakdown of the extracellular matrix. In these complex processes, Cyclooxygenase- 2 plays a major role in chronic inflammation and regulates matrix metalloproteinase- 9 expression significantly in tissue remodeling but the molecular mechanisms involved remain elusive.

\section{Aim}

To investigate the molecular mechanisms underlying Phosphatidyl-myo-inositol dimannosides triggered MMP-9 expression in macrophages.

\section{Methods}

We show possible implications of Notch signaling on immunological parameters associated with interaction of macrophages with novel cell wall antigen of Mycobacteria.

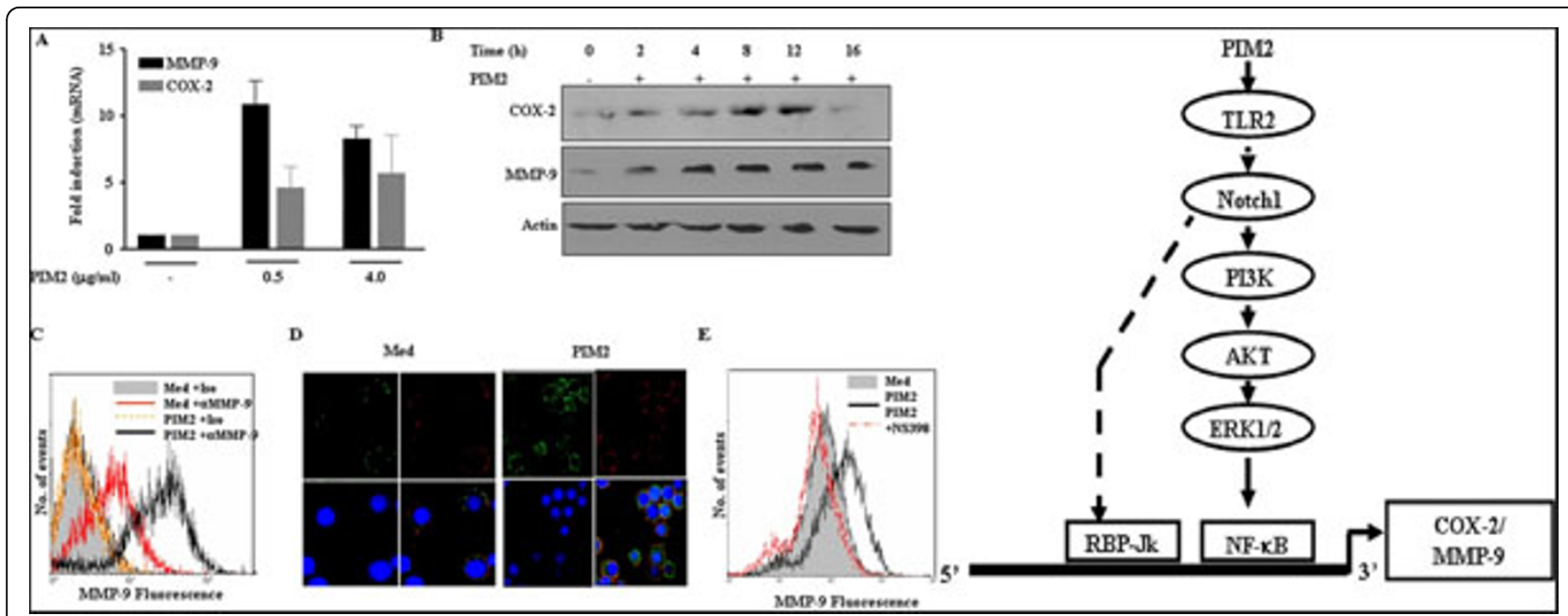

Figure 1 PIM2 induced COX-2 and MMP-9 expression and a model depicting signaling cascades regulating their expression: PIM2 treated macrophages shows upregulated COX-2 and MMP-9 expression both at mRNA and protein levels as analyzed by qRT-PCR, immunoblotting, FACS and confocal microscopy. Immunoflourescent staining of NS-398 treated macrophages shows decreased MMP-9 expression.

'Dept. of Microbiology and Cell Biology, Indian Institute of Science,

Bangalore, India

Full list of author information is available at the end of the article

C 2012 Kapoor et al; licensee BioMed Central Ltd. This is an Open Access article distributed under the terms of the Creative Commons 
We present evidences that PIM2 triggered expression of MMP-9 involves the activation of PI3K and Notch1 signaling in TLR2- MyD88 dependent manner.

\section{Results}

PIM2 triggers the activation of PI3K and Notch1 signaling leading to MMP-9 expression. Notch1 signaling perturbations demonstrate the involvement of a cross-talk with members of PI3K and MAPK pathway. PIM2 triggered significant p65 NF- $\kappa \mathrm{B}$ nuclear translocation that was dependent on activation of PI3K or Notch1 signaling. MMP-9 expression requires Notch1 mediated recruitment of Suppressor of Hairless (CSL) and NF- $\kappa \mathrm{B}$ to respective promoters.

\section{Conclusions}

PI3K and Notch1 signaling are obligatory early proximal signaling events during PIM2 induced MMP-9 expression in macrophages.

\section{Author details}

'Dept. of Microbiology and Cell Biology, Indian Institute of Science, Bangalore, India. ${ }^{2}$ Dept. of Mechanisms of Mycobacterial Infections, Université Paul Sabatier, Toulouse, France.

Published: 28 November 2012

\section{Reference}

1. Cosma $\mathrm{CL}$, Sherman DR, Ramakrishnan $\mathrm{L}$ : The secret lives of the pathogenic mycobacteria. Annu Rev Microbiology 2003, 57:641-676.

doi:10.1186/1479-5876-10-S3-P23

Cite this article as: Kapoor et al.: PIM2 induced MMP-9 expression in macrophages requires PI3K and Notch1 signaling. Journal of Translational Medicine 2012 10(Suppl 3):P23.
Submit your next manuscript to BioMed Central and take full advantage of:

- Convenient online submission

- Thorough peer review

- No space constraints or color figure charges

- Immediate publication on acceptance

- Inclusion in PubMed, CAS, Scopus and Google Scholar

- Research which is freely available for redistribution

Submit your manuscript at www.biomedcentral.com/submit 